\title{
The Potential and Pitfalls of Intersectionality in the Context of Social Rights
}

\section{Adjudication}

\author{
Colm O’Cinneide*
}

\section{Introduction}

Over the last thirty years, the concept of intersectionality has generated an impressive, extensive and steadily growing body of scholarship. Within the legal domain, intersectionality analysis is now routinely applied by academics and activists to critique the shortcomings of established anti-discrimination law and policy - in particular, its limited capacity to engage with the interlocking and mutually constitutive nature of structural inequalities. ${ }^{1}$ However, despite the conceptual ambition of such critique, and the enthusiasm with which it has been applied, it has generated relatively little in the way of tangible law reform. Intersectionality remains more talked about than implemented.

Having said that, interesting developments are afoot within human rights law. Doctrinal developments have opened up room for courts and other adjudicatory bodies to take account of intersectionality when reviewing state action for compliance with fundamental rights norms. This is particularly the case within an embryonic but growing area of human rights law, namely social rights adjudication.

For now, the relevant case-law is limited and patchy. It nevertheless highlights how intersectionality analysis can enhance human rights law, and deepen its capacity to engage with the dignity-corroding impact of poverty and material inequality. More generally, it also serves to emphasise how any serious attempt to give substance to social rights must grapple with

\footnotetext{
* Professor of Constitutional and Human Rights Law, UCL. Elements of this paper derive from reflection on my experience as a member of the European Committee on Social Rights, the monitoring body for the European Social Charter, between 2006 and 2016. However, none of the views expressed here should be taken to reflect the views of the Committee, in the past or at present. I am also grateful to the editors of this volume for their patient forbearance while this paper took shape.

${ }^{1}$ For a cross-jurisdictional sample of some recent legal research on this point, see S. Atrey, Intersectional Discrimination (Oxford University Press, 2019); D. Schiek, 'On the Use, Mis-Uses and Non-uses of Intersectionality before the Court of Justice of the EU' (2018) 18(2) International Journal of Discrimination and the Law 82; B. Goldblatt and L. Steele, 'Bloody Unfair: Inequality Related to Menstruation - Considering the Role of Discrimination Law' (2019) 41(3) Sydney Law Review 293; D. W. Carbado and K.W. Crenshaw, 'An Intersectional Critique of Tiers of Scrutiny: Beyond "Either/Or" Approaches to Equal Protection' (2019) 129 Yale Law Journal Forum 108.
} 
issues of intersectionality - while also spotlighting the need for intersectional analysis to engage properly with the primary role played by poverty and material inequality in generating structural inequalities within contemporary society. However, there are also certain conceptual traps that need to be avoided, if the development of this essential intersectional dimension to social rights adjudication is not to undermine the wider project of constructing a genuinely substantive and universally applicable framework of legal social rights protection.

Part I of this paper outlines the scope and ambition of intersectionality as a conceptual framework. Part II analyses how human rights law has developed in a way that opens up some limited room for the application of intersectionality analysis, principally through the related doctrinal concept of 'group vulnerability'. Part III examines how these developments are playing out in the specific and newly emerging field of social rights adjudication. Part IV examines the rich potential of intersectionality in this context. Part V concludes by analysing some of the conceptual traps that complicate the application of intersectionality analysis within social rights adjudication. Reference is primarily made to European legal standards, but the arguments made here are intended to be of general application.

\title{
I. The Ambitions of Intersectionality
}

Virtually all academic discussion of intersectionality begins by genuflecting to Kimberlé Crenshaw's famous 1989 paper on the topic. As is well known, Crenshaw argued that both feminist theory and anti-racist politics were limited by a failure to recognise the distinct forms of disadvantage inflicted by the overlap of different forms of discrimination:

\begin{abstract}
'[w]ith Black women as the starting point, it becomes more apparent how dominant conceptions of discrimination condition us to think about subordination as disadvantage occurring along a single categorical axis. I want to suggest further that this single-axis framework erases Black women in the conceptualization, identification and remediation of race and sex discrimination by limiting inquiry to the experiences of otherwise privileged members [white women/Black men] of the group.' 2
\end{abstract}

\footnotetext{
2 K. Crenshaw, 'Demarginalizing the Intersection of Race and Sex: A Black Feminist Critique of Antidiscrimination Doctrine, Feminist Theory and Antiracist Politics' (1989) 140 The University of Chicago Legal Forum 139, 154.
} 
Crenshaw's analysis of the impact of such 'intersectional discrimination' harkened back to the earlier insights of Audre Lorde, Barbara Smith and others involved in the Combahee River Collective, whose 1977 Statement had affirmed that 'the major systems of oppression are interlocking... [t] he synthesis of these oppressions creates the conditions of our lives' ${ }^{3}$ It was itself subsequently further developed by Crenshaw herself, as well as by other critical race feminists, such as Patricia Hill Collins. Over time, Crenshaw's original insights - focused primarily on the intersection of race and sex discrimination within the specific US context have morphed into a cross-disciplinary conceptual/analytical framework, used by scholars and activists across the world to critique the reproduction of social inequalities.

This critique emphasises: (i) the porous and mutually-constituting nature of social identities such as gender, class, race, age, disability and sexual orientation; (ii) the intersecting impact of the various forms of discrimination that play out across this complex web of identities; (iii) the way in which such 'intersectional discrimination' reinforces existing structural power hierarchies; and (iv) the limitations of anti-discrimination strategies structured around a single-axis approach, in particular those which adopt a particular 'baseline' identity as their de facto 'central case' and thus constrain their capacity to engage in any meaningful way with intersectional discrimination (e.g. Crenshaw's examples of white women/black men for sex/race discrimination respectively). ${ }^{4}$ More generally, it calls into question the traditional 'siloed' approach to combating oppressive power dynamics that play out along the different axes of gender, race, poverty/class and so forth, and encourages instead a turn towards a 'multidimensional' understanding of discrimination and the forms of critical praxis needed to combat it. $^{5}$

\footnotetext{
${ }^{3}$ The 'Combahee River Collective Statement', April 1977, published inter alia in J. S. Ritchie and K. Ronald (eds.) Available Means: An Anthology of Women's Rhetoric(s) (University of Pittsburgh Press, 2001), 292-300. See for an intellectual genealogy of intersectionality, see: A.M. Hancock, An Intellectual History of Intersectionality (Oxford University Press, 2016).

${ }^{4}$ Collins argues that intersectionality is based upon the insight that 'cultural patterns of oppression... are bound together and influenced by the intersectional systems of society, such as race, gender, class, and ethnicity'. P. H. Collins, 'Gender, Black Feminism, and Black Political Economy' (2000) 568 (1) Annals of the American Academy of Political and Social Science 41, 42.

${ }^{5}$ Collins suggests that intersectionality can function as a form of 'critical praxis', challenging the manner in which interlocking 'vectors of oppression' serve to perpetuate established inequalities; P. H. Collins, 'Intersectionality's Definitional Dilemmas' (2015) 41 (1) Annual Review of Sociology 1.
} 
In an era where individual and group identities have become more multi-faceted, ${ }^{6}$ and discrimination is increasingly conceptualised in more wide-ranging and variegated ways than was the case hitherto, this critique has resonated. ${ }^{7}$ Furthermore, intersectionality chimes with other critical approaches to equality, in particular those which aim to reconfigure social structures in line with the ambitions of 'substantive' or 'transformative' equality, as outlined by MacKinnon, Fredman, Anderson, Albertyn and others. ${ }^{8}$ Intersectionality shares with such perspectives an ambition to move beyond the ground-specific, formalist, de-contextualised approach of much existing equality law and policy, and towards a more substantive engagement with the multifaceted and structural nature of discrimination in contemporary societies. Its impact on contemporary debates about equality has both fuelled and been fuelled by the growing influence of this wider 'substantive' turn - with intersectionality critique being particularly influential in spotlighting how the interlocking impact of structural inequalities plays a distinctive role in reinforcing patterns of group subordination.

In general, intersectionality has come to exert a significant influence over how inequality is conceptualised across multiple academic disciplines, as well as in public debate. Intersectionality has even seeped into wider public discourse and gone 'viral'. ${ }^{9}$ However, in so doing, it has become somewhat caricatured - and a victim of the occasional political attack on so-called 'identity politics'. ${ }^{10}$ Furthermore, its impact on public discourse has not translated into much in the way of tangible policy outcomes. Confusion exists about what combating

\footnotetext{
${ }^{6}$ Malleson notes that there has been a 'shift in identity configurations', marked by the 'emergence of a much wider range of identity characteristics' and 'the increasing tendency to reconstruct identity characteristics along a spectrum': K. Malleson, 'Equality Law and the Protected Characteristics' (2018) 81(4) Modern Law Review 598. ${ }^{7}$ Intersectionality critique has both reflected and contributed to that process, by increasing awareness of the multidimensional nature of personal identity and the negative essentialising impact of overlapping forms of discrimination: see Malleson, ibid. Note, however, the recent significant argument made by Carbado and Harris that intersectionality should not be viewed as incompatible with essentialist perspectives on group disadvantage: see D. W. Carbado and C. I. Harris, 'Intersectionality at 30: Mapping the Margins of Anti-Essentialism, Intersectionality, and Dominance Theory’ (2019) 132 Harvard Law Review 2193.

8 See e.g. C. A. MacKinnon, 'Substantive Equality Revisited: A reply to Sandra Fredman' (2016) 14(3) International Journal of Constitutional Law 739-746; S. Fredman, 'Substantive Equality Revisited' (2016) 14(3) International Journal of Constitutional Law 712-738; E. Anderson, 'What is the Point of Equality?' (1999) 109(2) Ethics 287-337; C. Albertyn, 'Contested substantive equality in the South African Constitution: Beyond social inclusion towards systemic justice' (2018) 34(3) South African Journal on Human Rights 441-468.

9 J. Coaston, 'The Intersectionality Wars' (Vox, 28 May 2019)

https://www.vox.com/the-highlight/2019/5/20/18542843/intersectionality-conservatism-law-race-genderdiscrimination accessed 20 March 2020.

${ }^{10}$ See e.g. M. Continetti, 'The Battle of Woke Island' (National Review, 7 April 2018) https://www.nationalreview.com/2018/04/the-battle-of-woke-island/ accessed 20 March 2020. Continetti refers to "the post-modern dogma of "intersectionality" that promotes solipsism at the personal level and division at the social level'. Crenshaw has responded with understandable bemusement to this bowlderisation of her original concept: see Coaston, 'The Intersectionality Wars', ibid.
} 
'intersectional discrimination' actually entails. ${ }^{11}$ Scepticism also exists in policy-making circles about the potentially disruptive consequences of departing from the deeply embedded 'single-axis' approach to non-discrimination.

As a result, intersectionality remains more talked about than implemented, especially when it comes to legislative protection against discrimination. ${ }^{12}$ However, recent developments in human rights law have seen courts and other adjudicatory bodies begin to engage with the structural impact of intersectional inequalities - with the embryonic field of social rights law being to the fore in this regard. This generates some interesting and complex issues. However, before these are discussed, it is necessary to set out exactly how human rights law has begun to gradually acquire an intersectional dimension, and the particular importance of this in respect of social rights.

\section{The Emerging Intersectional Dimension to Human Rights Jurisprudence}

Following Crenshaw's lead in her 1989 paper, intersectionality critique has repeatedly highlighted the limitations of how legal systems conceptualise discrimination and inequality more generally. Historically, legal systems have defined discrimination by reference to the 'single-axis' approach critiqued by Crenshaw (i.e. the assumption that discriminatory treatment plays out along neat vectors that align with the traditional protected grounds, such as race, sex, and disability). Furthermore, it has tended to adopt a largely formal approach to defining what qualifies as discrimination, which focuses on the rationale for less favourable treatment rather than on its substantive impact on disadvantaged groups within a specific context. Taken together, these characteristics have limited the capacity of law to address more complex and substantive forms of discrimination - including intersectional discrimination.

However, the old assumptions, which underpinned the traditional 'siloed' approach of law to such issues are breaking down - in part thanks to the prodding of intersectionality critique. ${ }^{13}$ The single-axis approach to defining discrimination no longer tallies with

\footnotetext{
${ }^{11}$ A. Christofferson, "Are We All "Baskets of Characteristics?" Intersectional slippages and the displacement of race in English and Scottish equality policy' in J.S. Jordan-Zachery and O. Hankivsky (eds.), The Palgrave Handbook of Intersectionality in Public Policy (Palgrave, 2019) 705.

${ }^{12}$ This is particularly true of legislative non-discrimination frameworks, which remain generally wedded to a 'single-axis' approach despite sustained criticism on this point from academics and activists.

${ }^{13}$ Malleson, above at n. 6.
} 
contemporary views about the multi-faceted nature of personal identity and the overlapping impact of structural inequalities. In addition, formal conceptions of equality are giving way to more substantive understandings of the concept - with discrimination increasingly viewed in terms of its systemic and structural impact, rather than as the product of wrongly-motivated individual decisions motivated by specific ground-based prejudicial attitudes. ${ }^{14}$

It is, thus, no surprise that intersectionality looms large in debates about the future development of law in this area. In the eyes of many expert commentators, an embrace of intersectionality should form part of the next stage of the evolutionary development of equality - as part of a wider upgrade to a fully fleshed-out commitment to substantive equality.

Such intersectionality critique has particularly featured in debates about the future of anti-discrimination legislation, such as the UK's Equality Act 2010 or the EU equality directives. As already noted, in this context, intersectionality has generated considerable heat - but little in the way of substantive legal reform. ${ }^{15}$ However, such critique can also be applied to other aspects of law, in particular to human rights law - both as regards its specific equality and non-discrimination provisions, and also its wider package of substantive rights guarantees.

Human rights instruments, whether they be national constitutional charters or international treaties, invariably contain provisions requiring respect for the right to equality and non-discrimination. Such 'equality clauses', like art. 15 of the Canadian Charter of Fundamental Rights and Freedoms and art. 14 of the European Convention on Human Rights (ECHR), are often 'open-ended' in scope (i.e. the protection they offer against discrimination is not necessarily confined to a specific set of equality grounds, unlike the case with most national anti-discrimination legislation). However, they are generally interpreted and applied by courts and other adjudicative bodies in line with the standard single-axis approach. Furthermore, such clauses are usually interpreted in a formalistic, de-contextualised manner which often reflects the 'baseline' identity assumptions critiqued by Crenshaw.

But attitudes are beginning to change, on both fronts - reflecting in part the influence of intersectionality critique, and also the wider influence of the substantive turn in equality

\footnotetext{
${ }^{14}$ See the authors cited at n.8 above.

${ }^{15}$ Note, for example, that the 'combined discrimination' provisions of s. 14 of the UK Equality Act 2010 have not come into force, as the necessary ministerial authorisation has not been forthcoming.
} 
law. ${ }^{16}$ A range of national courts, along with the European and Inter-American Court of Human Rights and other international human rights adjudicatory bodies, have in recent years begun to adopt what Atrey has described as a 'flexible' and context-sensitive approach to comparator analysis. ${ }^{17}$ They have also shown greater willingness to review state action that discriminates on a combination of status grounds, in particular when it impacts upon groups deemed to be 'vulnerable' on account of their disadvantaged social status. This amplifies the ability of such courts to engage with multiple discrimination broadly defined, including intersectional discrimination.

For example, the Strasbourg Court has begun to take account of the vulnerable status of particular groups in determining the scope of state obligations under art. 14 ECHR. ${ }^{18}$ State action which subjects such groups to particular disadvantage can be subject to more intensive review than applied in other contexts, while states may also be subject to positive obligations to take special measures to secure equality of treatment for such groups. Crucially, the Court has been willing to extend this protection to groups whose vulnerability is generated by the overlapping impact defined by two or more structural patterns of social exclusions - thereby opening the door to intersectional concerns.

The stand-out case in this regard thus far is B.S. v Spain, ${ }^{19}$ where the Strasbourg Court found a violation of art. $14 \mathrm{ECHR}$, taken with art. $3 \mathrm{ECHR}$, in respect of a failure to investigate allegations of police harassment directed towards an African woman working as a prostitute. The Court recognised the applicant's 'particular vulnerability' arising from the intersection of her gender and ethnic origin, taken together with the nature of her work. ${ }^{20}$ Also, more recently, in the case of $J D$ and $A v U K,{ }^{21}$ the Court concluded that the UK had breached art. 14 ECHR in deducting housing benefits from mothers who had been the victims of domestic violence but were nevertheless deemed to be occupying accommodation with more space than their families

\footnotetext{
16 See, in general, S. Fredman, Human Rights Transformed: Positive Rights and Positive Duties (Oxford University Press, 2008).

${ }^{17}$ S. Atrey, 'Comparison in Intersectional Discrimination' (2018) 38(3) Legal Studies 379-395.

${ }^{18}$ L. Peroni and A. Timmer, 'Vulnerable Groups: The promise of an emerging concept in European Human Rights Convention Law' (2013) 11(4) International Journal of Constitutional Law 1056-1085.

${ }^{19}$ App. no. 47159/08, Judgment of 24 July 2012.

${ }^{20}$ See M. C. La Barbera and M. C. López, 'Toward the Implementation of Intersectionality in the European Multilevel Legal Praxis: B. S. v. Spain' (2019) 53(4) Law and Society Review 1167-1201.

${ }^{21}$ App. nos. 32949/17 and 34614/17, Judgment of 24 October 2019.
} 
required, notwithstanding that the accommodation in question had been specially modified to ensure their personal safety.

In both these cases, the Court recognised that state parties owed particular obligations to specific groups of women defined by overlapping forms of disadvantage: in $B S$, the structural inequalities arising by virtue of the intersection of the claimant's ethnicity and profession, and in $J D$, those arising by virtue of the claimant's dependence on social welfare support taken together with her status as a survivor of serious domestic violence. Respect for the right to equality under art. $14 \mathrm{ECHR}$ was thus deemed to require special state action to take account of the particular vulnerability of the claimants generated by the impact of intersecting forms of structural inequalities - showing how this developing strand of the Court's case law is potentially able to accommodate intersectionality, in situations of clear 'group vulnerability' at least.

This vulnerability approach has only been partially integrated into the Strasbourg jurisprudence. ${ }^{22}$ It is not always applied in a consistent or rigorous manner. Furthermore, the Court's case law in this context has sometimes been criticised for reinforcing negative stereotyping about the alleged inherent powerlessness of such 'vulnerable' groups. ${ }^{23}$ Nevertheless, the relevant ECHR case law recognises that the overlapping impact of various structural power imbalances may have a particularly negative impact upon specific groups, in ways that do not readily qualify as straightforward instances of single-axis, ground-specific discrimination. It thus reflects aspects of intersectionality critique: even though the framing concept of 'vulnerability' - which perhaps reflects the influence of Martha Fineman's theorising ${ }^{24}$ - is wider in scope and has a different genealogy and definitional logic, it shares with intersectionality a common focus on the specific contextual impact, and can serve as a vector for judicial recognition of the interlocking impact of structural inequalities.

A similar approach as adopted by the ECtHR has been adopted by a range of UN and other Council of Europe bodies in determining the scope of state obligations arising by virtue

\footnotetext{
${ }^{22}$ O. Arnardóttir, 'Vulnerability under Article 14 of the European Convention on Human Rights: Innovation or Business as Usual?' (2017) 4(3) Oslo Law Review 150.

${ }^{23}$ Peroni and Timmer, n. 18 above. See also K. Nieminen, 'Eroding the Protection against Discrimination: The Procedural and De-contextualized Approach to S.A.S. v France' (2019) 19(2) International Journal of Discrimination and the Law 69.

${ }^{24}$ M. A. Fineman, 'The Vulnerable Subject: Anchoring Equality in the Human Condition' (2008) 20(1) Yale J.L. \& Feminism 1-23.
} 
of the various equality rights guaranteed in human rights treaty instruments. Indeed, certain international human rights bodies have explicitly recognised intersectional discrimination as constituting a breach of such equality rights. For example, the Committee on the Elimination of Discrimination against Women has stated that intersectionality is a 'basic concept for understanding the scope of the general obligations of States parties' under the UN Convention on the Elimination of All Forms of Discrimination Against Women (CEDAW) ${ }^{25}$ National courts have also shown some openness in this regard, albeit while generally moving with baby steps. $^{26}$

Analogous case law developments are also under way in other areas of human rights law, beyond the specific scope of application of 'equality clauses'. Courts and other adjudicatory bodies are increasingly recognising that the scope and substance of state human rights obligations in general may vary according to the contextual status of groups. Specific obligations may arise in respect of certain vulnerable groups across a range of fundamental rights, just as happens in relation to equality rights narrowly defined. ${ }^{27}$ Furthermore, such vulnerability is increasingly defined by reference to overlapping identities. This again opens a door to intersectionality considerations.

Thus, in Yordanova $v$ Bulgaria, ${ }^{28}$ the ECtHR held that eviction notices issued against a socio-economically disadvantaged Roma community constituted a disproportionate interference with art. $8 \mathrm{ECHR}$, on the basis that the 'underprivileged status' of this community and their need for alternative housing arrangements were not adequately taken into account. This represents a development of the Court's vulnerability approach, extended beyond the specific framework of art. 14 ECHR. And, again, it opens the door to intersectionality concerns - as neatly illustrated in Yordanova by how the Court implicitly acknowledged that patterns of social exclusion rooted in the overlap of socio-economic disadvantage and ethnicity had

\footnotetext{
${ }^{25}$ CEDAW, General Recommendation No. 28: The Core Obligations of State Parties under Article 2 of the Convention on the Elimination of All Forms of Discrimination against Women, 16 December 2010, [18]. For the situation in respect of the UN Convention on the Rights of Persons with Disabilities, see G. De Beco, 'Intersectionality and Disability in International Human Rights Law' (2019) The International Journal of Human Rights, DOI: 10.1080/13642987.2019.1661241.

${ }^{26}$ S. Atrey, Intersectional Discrimination (OUP, 2019), Ch 1.

${ }^{27}$ See Peroni and Timmer. n. 18 above.

${ }^{28}$ App. no. 25446/06, Judgment of 24 April 2012, [133]. The Court took the view that the Art. 14 EHCR claim brought by the applicant was subsumed within the Art. 8 ECHR complaint, [145]-[149]. See also Connors $v$ UK (2005) 40 EHRR 9.
} 
generated the uniquely vulnerable status of the particular Roma community affected by eviction in this case.

Similar case law developments can be identified elsewhere in national, regional and international human rights jurisprudence. ${ }^{29}$ In such decisions, the specific characteristics of vulnerable or targeted groups are increasingly taken into account in determining both (i) the scope of the right at issue and the obligations it imposes upon states, and the (ii) adequacy of any justification offered for state interference with this right. Again, this has opened the way for intersectional factors to be taken into account across a spectrum of human rights.

It is important not to exaggerate the extent of these case law developments. At present, intersectionality critique occupies at best a marginal place in debates about the scope and substance of human rights law taken as a whole. ${ }^{30}$ However, avenues have opened up within human rights law for the application of intersectionality analysis. This in turn highlights the potential of intersectionality critique to 'bite' in the field of human rights in general. Patterns of social exclusion often overlap, generating intersectional forms of inequality, which can impact profoundly on the enjoyment of an assortment of human rights. Intersectionality critique can help to diagnose these potential blind-spots, and thus offers a way of deepening the substantive turn in equality law and within human rights jurisprudence at large. ${ }^{31}$

\section{Intersectionality and Social Rights}

So, given all the above, how do social rights fit into the picture? What does intersectionality have to say to law and policy approaches that engage with social rights considerations, or bear some link to their interpretation and development?

\section{A. The Emergence of Social Rights Jurisprudence}

Some context is necessary here. Social rights, such as the right to education or the right to social security, have been for a long time a missing piece in the puzzle of human rights law.

\footnotetext{
${ }^{29}$ See Peroni and Timmer, n. 18.

${ }^{30}$ P. Y. S. Chow, 'Has Intersectionality Reached its Limits? Intersectionality in the UN Human Rights Treaty Body Practice and the Issue of Ambivalence' (2016) 16(3) Human Rights Law Review 453.

${ }^{31}$ G. De Beco, 'Protecting the Invisible: An Intersectional Approach to International Human Rights Law' (2017) 17(4) Human Rights Law Review 633.
} 
Their importance as political concepts has been acknowledged from the inception of the modern human rights era, as reflected in the extensive list of such rights acknowledged in the text of the Universal Declaration of Human Rights 1948. They receive plenty of lip service as important guarantors against the worst excesses of poverty and material inequality. However, at both national and international levels, deep scepticism has persisted about the desirability of protecting them through law. Until recently, national legal systems made very little provision - if any - for such rights to be enforceable in law. The international mechanisms for monitoring state compliance with such rights were also very limited. Indeed, if anything, social rights constituted something of a legal 'exclusion zone': they were widely viewed as not fit subjects for legal enforcement. ${ }^{32}$

However, things have begun to change. As Leitjen puts it, using a neat German phrase, social rights are increasingly acknowledged to be salonfähig (i.e. presentable in good legal company). ${ }^{33}$ The absence of a social dimension to national and international human rights law is now increasingly regarded as a defect, which limits its capacity to protect essential aspects of human dignity. ${ }^{34}$ This has generated greater willingness on the part of judges and law-makers to extend the scope of human rights law into socio-economic terrain. As a result, two methods of protecting social rights through law have emerged.

First there is the 'indirect' route, whereby established legal guarantees covering 'core' civil and political rights - including equality and non-discrimination rights - are interpreted in a way that protects individual access to certain social entitlements. Thus, in $R$ (Adam and Limbuela) v Secretary of State for the Home Department, ${ }^{35}$ the UK House of Lords held that denying welfare benefits to asylum seekers who were prohibited from seeking work risked exposing them to a level of destitution that qualified as inhuman and degrading treatment - and thus would qualify as a breach of art. 3 ECHR. Similarly, in M.S.S. v Belgium and Greece, the $\mathrm{ECtHR}^{36}$ ruled that the conditions in which refugees were living in Greece constituted a breach of art. 3. The $J D$ and Yordanova judgments cited above are further examples of civil and

\footnotetext{
${ }^{32}$ C. O'Cinneide, 'The Problematic of Social Rights - Uniformity and Diversity in the Development of Social Rights Review' in L. Lazarus, C. McCrudden and N. Bowles (eds.), Reasoning Rights: Comparative Judicial Engagement (Hart, 2014), 297-315.

${ }^{33}$ I. Leitjen, 'Book Review - The Future of Economic and Social Rights' (2019) 17(4) International Journal of Constitutional Law 1354, 1354.

${ }^{34}$ See, in general, J. King, Judging Social Rights (Cambridge University Press, 2012).

${ }^{35}$ [2005] UKHL 66.

36 (2011) 53 EHRR 2.
} 
political rights being interpreted in a way that protects individuals and groups against unjustified deprivation of welfare support and public housing respectively. This indirect approach is inherently limited, as it only protects those aspects of social rights that can be shoehorned into the framework of a civil and political rights claim. However, it protects individuals against egregious breaches of their social rights in situations where such 'shoehorning' is possible - and where state responsibility is clearly engaged. ${ }^{37}$

The 'direct' approach sets out to protect social rights through the establishment of national or international legal mechanisms which directly review state compliance with such rights. Examples include the Optional Protocol mechanism to the International Covenant on Economic, Social and Cultural Rights (ICESCR), whereby individuals can bring claims alleging a breach of ICESCR to the UN Committee on Economic, Social and Cultural Rights (CESCR); the 'collective complaint' mechanism provided for under the European Social Charter (ESC), which allows certain types of NGOs and 'representative bodies' to bring complaints of a Charter violation to the European Committee on Social Rights (ECSR); and the constitutional mechanisms for reviewing the adequacy of state measures to give effect to social rights established in states, such as South Africa, Colombia and Portugal. ${ }^{38}$ Such mechanisms obviously give more comprehensive protection to social rights than is available via the indirect route, and permit closer legal engagement with their substance. They also complement the normative approach to social rights that has been developed by various UN Special Rapporteurs in relation to issues such as access to housing, water and food and the fight against extreme poverty. However, the trade-off is that the impact of international social rights mechanisms is often muted, and scepticism persists about the desirability or workability of such direct enforcement of social rights standards. ${ }^{39}$

Neither indirect nor direct approaches can yet be said to have become an integral part of the mainstream of human rights law. But their emergence is a clear sign that social rights are now squarely on the human rights law agenda. There is growing support for human rights law to acquire a meaningful 'social dimension', and to acquire the capacity to address dignityeroding measures, which generate poverty and material inequality. This again reflects the

\footnotetext{
${ }^{37}$ O'Cinneide, 'The Problematic of Social Rights', n. 33 above.

${ }^{38}$ See in general J. Dugard et al (ed.), Research Handbook on Economic, Social and Cultural Rights as Human Rights (Elgar, 2020).

${ }^{39}$ O'Cinneide, 'The Problematic of Social Rights', n. 33 above.
} 
existence of the abovementioned dynamic of reform and reinvigoration, and the desire to make human rights law more responsive to existing patterns of social exclusion. ${ }^{40}$ Given this ambition, intersectionality critique offers some important lessons for how social rights protection should develop. Its emphasis on the specific and contextual nature of intersectional discrimination - and the need for this to be taken into account across the full spectrum of human rights standards - has particular relevance for this developing area of law.

\section{B. Intersectionality as a Necessary Ingredient for Social Rights Adjudication}

The impact of poverty and material inequality may play out in different registers across different social contexts, and impact differently on different groups. In particular, inadequate protection for social rights, or cuts to existing levels of protection, may overlap with other forms of discriminatory or exclusionary treatment in a way that imposes particular disadvantages on specific groups. ${ }^{41}$ Structural deficiencies, blind-spots or other limitations in social rights protection will often have a disproportionate impact on groups already subject to structural disadvantages in the labour market or other forms of discriminatory treatment. Furthermore, the intersection of poverty/material inequality with ascribed identity grounds, such as race, disability and gender has historically been a major generator of specific disadvantage and continues to be so today. ${ }^{42}$

As such, a single-axis, 'one size fits all' approach to social rights, which fails to take factors, such as gender, race, and disability into account when assessing the legitimacy of state action impacting upon such rights, risks being too reductionist. Particular limitations on the enjoyment of social rights might be defensible in terms of their general impact, but not as regards their disproportionate impact upon a specific sub-group delineated by two or more characteristics (including the socio-economic vulnerability generated by the social rights restriction in question). If a form of social rights review - whether indirect or direct in nature

\footnotetext{
${ }^{40}$ King, Judging Social Rights, n .35 above; C. O'Cinneide, 'The Constitutionalisation of Socio-economic Rights' in H. Alviar García, K. Klare, L. Williams (eds.), Socio-economic Rights in Theory and Practice: Critical Inquiries (Routledge, 2014), 258-276.

${ }^{41}$ S. Atrey, 'The Intersectional Case of Poverty in Discrimination Law' (2018) 18 Human Rights Law Review 411.

${ }^{42}$ B. Goldblatt, 'Intersectionality in International Anti-discrimination Law: Addressing poverty in its complexity', (2015) 21(1) Australian Journal of Human Rights 47-70; by the same author, Developing the Right to Social Security - A Gender Perspective (Routledge, 2016); M. Maroto, D. Pettinicchio and A. C. Patterson, 'Hierarchies of Categorical Disadvantage: Economic Insecurity at the Intersection of Disability, Gender, and Race' (2019) 33 Gender and Society 64.
} 
- confines itself to assessing the general impact of the restriction under review, then such group-specific disproportionate impacts will be left out of the picture. This would replicate the 'baseline' problem identified by Crenshaw, gloss over particular contexts where overlapping forms of social exclusion have especially concentrated effect, and generate the type of narrow, formalist analysis that is increasingly depreciated across the spectrum of human rights law. In other words, it would be wide open to the intersectionality critique - and deviate from the contextual, substantive approach increasingly adopted in other areas of human rights adjudication, especially equality law.

\section{The Embrace of Intersectionality in Social Rights Adjudication}

Given this, it is not surprising that both indirect and direct forms of social rights adjudication have grappled with intersectional issues. The concept of 'vulnerability' has again played an important role in this regard, serving as the vector for the type of contextual and group-focused analysis that opens the door to intersectionality considerations.

For example, in the 'indirect' $J D$ and Yordanova cases cited above, the ECtHR engaged in close analysis of the specific context in which the claimants found themselves - and it concluded that the state parties in question had failed to take adequate account of claimants' particular vulnerabilities, as generated by the intersection of socio-economic status and gender $(J D)$ and socio-economic status and race (Yordanova) respectively.

Direct forms of social rights adjudication have also engaged with intersectional forms of discrimination and social exclusion. For example, in its collective complaints case law, the ECSR has repeatedly engaged with intersectional issues - albeit generally again through the specific lens of 'vulnerability'. Indeed, complaints concerning the situation of specific minority groups subject to overlapping forms of social exclusion have made up a substantial part of the Committee's case law. This is striking, given that the ECSR's case law is perhaps one of the best developed set of legal social rights norms that currently exists at the international level: it illustrates how intersectionality concerns are directly relevant to the business of social rights adjudication. 
In Complaint 15/2003, ERRC v. Greece, the Committee stated that one of the underlying purposes of the social rights protected by the Charter is to express solidarity and promote social inclusion - and that state parties must take the particular needs of minority groups into account when taking measures to address social exclusion. ${ }^{43}$ The Committee went on to conclude that the available evidence clearly indicated that local authorities in Greece were failing to take proportionate steps to address the specific housing needs of the Roma minority, which arose by virtue of their particular status as a social group that had been historically marginalised by the intersection of ethnicity and socio-economic status.

Subsequently, in Complaint 27/2004, ERRC v. Italy, the Committee concluded that the inadequate supply of housing for Roma communities in Italy, the failure to take into account their specific accommodation needs, and a failure by local authorities to implement administrative decrees requiring the provision of adequate shelter and support for these communities constituted a violation of art. 31 of the revised ESC (right to housing), taken together with the right to equality and non-discrimination set out in art. E. ${ }^{44}$ In later cases, the Committee affirmed the need for state parties to take the special situation of Roma and Traveller communities into account in implementing eviction procedures, ${ }^{45}$ and to take protective action where required to defend Roma housing sites against xenophobic attacks and other forms of discriminatory action. ${ }^{46}$ In Complaint 46/2007, ERRC v. Bulgaria, the Committee extended this logic into the area of health care, concluding that Bulgarian health care provision policies did not adequately address the specific health risks affecting Romani communities. $^{47}$

Beyond the specific context of the Roma, the Committee has also applied similar logic in concluding that Belgium had breached the Social Charter's requirements by failing to take adequate measures to secure the fundamental social rights of distinct groups of persons with

\footnotetext{
${ }^{43}$ Decision on the merits of 7 February 2005. In this respect, the ECSR cross-referred to the judgment of the European Court of Human Rights in Connors v. UK (2005) 40 EHRR 9. The Committee subsequently reiterated its findings in this regard in INTERIGHTS v. Greece, Complaint No. 49/2008 (decision on the merits of 25 January 2010).

${ }^{44}$ Decision on the merits, 21 December 2005: see in particular $\S \S 18-19$. See also ERRC v. Portugal, Complaint No. 49/2008 (Decision on the merits of 1 July 2011).

${ }^{45}$ ERRC v. Bulgaria, Complaint 31/2005 (Decision on the merits of 1 July 2011).

${ }^{46}$ Centre on Housing Rights and Evictions (COHRE) v. Italy, Complaint No. 58/2009 (Decision on the merits of 6 July 2010); COHRE v. France, Complaint No. 63/2010 (Decision on the merits of 13 July 2011).

${ }^{47}$ Médecins du Monde v. France, Complaint 67/2011 (Decision on the merits of 20 September 2012).
} 
disabilities; ${ }^{48}$ Italy had failed to provide pregnant women living in particular geographical regions with secured access to abortion services (classified in that specific national context as constituting an aspect of the right to health care); ${ }^{49}$ Finland had failed to take account of the specific socio-economic situation of particular groups of older persons in receipt of social care ${ }^{50}$ and the Netherlands had failed to give due regard to the specific situation of irregular child refugees in denying them secured access to emergency shelter. ${ }^{51}$ In all of these cases, the Committee recognised the vulnerabilities of specific social groups defined by the intersecting impact of two or more 'logics' of social exclusion, and took that vulnerability into account in evaluating whether the state parties in question had failed to take adequate steps to discharge their positive obligations under the ESC. ${ }^{52}$

At the UN level, the CESCR has also taken account of the specific situation of vulnerable groups defined by the intersecting impact of overlapping forms of social exclusion in reviewing state compliance with their ICESCR obligations. ${ }^{53}$ For example, in its merits decision in the individual complaint of Djazia and Bellili $v$ Spain,${ }^{54}$ brought under the Optional Protocol to the ICESCR that permits such complaints, the Committee concluded that Spain had failed to take adequate steps to secure the right to housing of families in deprived socioeconomic circumstances who faced a threat of eviction. Similarly, in Calero $v$ Ecuador ${ }^{55}$ the

\footnotetext{
${ }^{48}$ Mental Disability Advocacy Center (MDAC) v. Bulgaria; Complaint 41/2007 (Decision on the merits of 10 June 2008); International Federation of Human Rights (FIDH) v. Belgium, Complaint No. 75/2011 (Decision on the merits of 26 March 2013).

${ }^{49}$ International Planned Parenthood Federation - European Network (IPPF EN) v. Italy, Complaint No. 87/2012 (Decision on the merits of 10 September 2013).

${ }^{50}$ The Central Association of Carers in Finland v. Finland, Complaint No. 70/2011 (Decision on the merits of 4 December 2012).

${ }^{51}$ Defence of Children International v. The Netherlands, Complaint No. 47/2008 (Decision on the merits of 20 October 2009).

${ }^{52}$ The Committee thus primarily uses group vulnerability as an evaluative tool in assessing the adequacy of state measures to give effect to social rights, rather than as a 'status' ground for the purpose of non-discrimination analysis: see the discussion below in Part V of this chapter of the Committee's decision in Collective Complaint No 48/2008, ERRC v Italy, Decision on the Merits of 31 March 2009.

${ }^{53}$ See, in general, S. Liebenberg, 'Between Sovereignty and Accountability: The Emerging Jurisprudence of the United Nations Committee on Economic, Social and Cultural Rights under the Optional Protocol' (2020) 42(1) Human Rights Quarterly 48-84.

${ }^{54}$ Djazia and Bellili v. Spain, Views Adopted by the Committee under the Optional Protocol to the International Covenant on Economic, Social and Cultural Rights with Regard to Communication No. 5/2015, U.N. ESCOR, Comm. on Econ., Soc. \& Cult. Rts., 61st. Sess., II 11.5, U.N. Doc. E/C.12/61/D/5/2015 (2017).

${ }^{55}$ Calero v. Ecuador, Views Adopted by the Committee under the Optional Protocol to the Covenant Concerning Communication No.10/2015, U.N. ESCOR, Comm. on Econ., Soc. \& Cult. Rts., 63rd Sess., III 9.4-9.5, U.N. Doc. E/C.12/63/D/10/2015 (2018). As Liebenberg notes, the complainant had 'experienced intersectional discrimination on the grounds of gender and age', in addition to suffering a deprivation of social security protection: Liebenberg, n. 50 above, 80.
} 
Committee decided that Ecuador had failed to take adequate measures to secure the right to social security for older female domestic workers.

In its General Comment No. 20, the CESCR has expressly recognised that individuals or groups may face 'cumulative discrimination' on two or more grounds, which merits 'particular consideration and remedying' by state parties. ${ }^{56}$ It also indicates that a violation of the ICESCR may be generated by 'the intersection of two prohibited grounds of discrimination, e.g. where access to a social service is denied on the basis of sex and disability'. ${ }^{57}$ UN Special Rapporteurs have adopted a similar stance with, for example, successive Special Rapporteurs on the right to housing emphasising how the impact of lack of security of tenure is often amplified by the intersecting impact of factors, such as gender, race and disability. ${ }^{58}$ As Atrey has argued, some traces of a willingness to engage with the intersecting impact of poverty and other discrimination grounds is even detectable in the social rights jurisprudence of certain national courts. 59

In general, a similar dynamic is thus playing out in the context of social rights adjudication as for equality law and human rights law more generally. Courts and other adjudicatory bodies are recognising that the scope of social rights obligations may vary according to the contextual status of the affected groups - and, in particular, the extent of their vulnerability, increasingly defined by reference to the intersecting impact of different forms of social exclusion.

\section{What Intersectionality Contributes to Social Rights Adjudication: The Complex Interface between Poverty, Material Inequality and Identity Discrimination}

For now, this vulnerability approach is at an embryonic stage of development (as is true for social rights jurisprudence more generally). However, the salience of intersectional issues thus far in its development is striking. It confirms the relevance of intersectionality critique to social

\footnotetext{
${ }^{56}$ General Comment No. 20, Non-Discrimination in Economic, Social and Cultural Rights, U.N. ESCOR, Comm. on Econ., Soc. \& Cult. Rts., 42d Sess., Agenda Item 3, II 5, U.N. Doc. E/C.12/GC/20 (2009), [17].

57 ibid, [27].

${ }^{58}$ See e.g. UNHRC, Report of the Special Rapporteur on adequate housing as a component of the right to an adequate standard of living, and on the right to non-discrimination in this context, Miloon Kothari, 13 February 2008, UN Doc No. A/HRC/7/16, [40]; UNHRC, Report of the Special Rapporteur on adequate housing as a component of the right to an adequate standard of living, and on the right to non-discrimination in this context, Raquel Rolnik, 26 December 2011, UN Doc No. A/HRC/19/153, [1]-[3].

${ }^{59}$ Atrey, 'The Intersectional Case of Poverty in Discrimination Law', n. 42 above.
} 
rights adjudication, and its potential to add depth to its development. Discourse about material inequality and social rights has sometimes glossed over the role played by discrimination based on ascribed identity grounds, such as gender, race or disability in reinforcing patterns of poverty and social exclusion. ${ }^{60}$ However, the accommodation of intersectionality within social rights jurisprudence has the potential to bring these two dimensions of equality together. It lays down foundations for the development of a multidimensional understanding of social rights, which would be capable of engaging with the multiplicity of factors that generate social exclusion - and, in particular, the complex ways in which material inequality can intersect with other modes of discriminatory treatment. It also underscores that, as Conaghan puts it, 'all inequalities are intersectional': the inequalities generated by poverty and material inequality are co-constituted by, and inherently bound up with, multiple other interlocking forms of structural disadvantage. ${ }^{61}$

In this regard, it is also worth highlighting that the emergence of social rights jurisprudence is, in itself, significant from an intersectionality perspective. For, by enlarging the scope and substance of human rights law, it also enlarges its capacity to engage with the greatest generator of social inequality - namely poverty and the consequences of material inequality. ${ }^{62}$ And, by extension, this also extends its capacity to address the intersectional impact of poverty and material inequality taken in combination with other discriminatory factors. As Atrey has noted,

' $[\mathrm{t}]$ he vast canon on intersectionality, which spans far beyond discrimination law and its notion of grounds, has thus centred on unravelling and addressing the complexity of intersectional disadvantage and discrimination suffered by people. Seen from this perspective, poverty or poverty discrimination appears to be a paradigmatic intersectional case. It is intersectional not only in terms of its complex

\footnotetext{
${ }^{60}$ See Stuart Hall's penetrating comments on this topic: the critique 'that [political correctness] concerns itself with irrelevant and trivial issues as compared with the "real" questions of poverty, unemployment and economic disadvantage... is the product of an archaic view, a sort of crass, low-flying materialism, that "class" is both more real and more simple to address than, say, gender; that "class", because it is linked to the economic, is somehow more materially determining, and that the economic... factors work as it were on their own, outside of their social and ideological, their gendered and "raced" conditions of existence'; S. Hall, 'Some "Politically Incorrect" Pathways through PC' in S. Dunant (ed.), The War of the Words. The Political Correctness Debate (Virago, 1994) 164-184.

${ }^{61}$ J. Conaghan, 'Intersectionality and the Feminist Project in Law' in D. Cooper et. al. (eds.), Law, Power and the Politics of Subjectivity: Intersectionality and Beyond (Routledge, 2008) 21-48, 42.

${ }^{62}$ Malleson, n. 6 above.
} 
structural disadvantage which goes beyond the level of income or wealth towards a broader conception of harms including loss of dignity and autonomy, social exclusion and so on, but also because it cuts across other systems of subordination associated with status groups like Blacks, women, Roma, Dalits, gays, disabled, the aged and so on. ${ }^{63}$

However, human rights law in general - and equality law in particular - has historically provided little or no meaningful legal protection against the socially exclusionary impact of poverty and material inequality. ${ }^{64}$ This has been viewed as a problem outwith the concerns of law: something for the political branches of the state to address, but a 'zone of exclusion' for court-focused remedies. ${ }^{65}$ As a result, as Atrey has noted, courts have been very slow to extend existing parameters of equality law or rights jurisprudence to engage with the impact of poverty-related discrimination. ${ }^{66}$ In turn, this has hampered the already constrained ability of the law to engage with intersectional discrimination: legal systems generally lack the capacity to respond in any meaningful way to how poverty and material inequality amplify the impact of other forms of inequality.

Furthermore, this lack of legal protection has arguably also helped to obscure the intersectional impact of poverty and material inequality more generally, within both public policy debates and conceptual discussions about intersectional discrimination. To quote Atrey again:

'poverty in discrimination law has been understood not in intersectional terms... but as a fragmented or simplistic case of economic redistribution which has nothing to do with other forms of disadvantage and discrimination of status groups...[T]his omission appears neither calculated nor well-meaning but based on an unquestioning assumption of the dominant framework in discrimination law which is too removed from complex

\footnotetext{
${ }^{63}$ Atrey, 'The Intersectional Case of Poverty in Discrimination Law', n. 42 above.

${ }^{64}$ In part, this has reflected the divide famously identified by Nancy Fraser between scholars and activists primarily concerned with social redistribution and those focused on 'recognition' issues relating to the ascribed identity grounds; N. Fraser, 'Social Justice in the Age of Identity Politics: Redistribution, Recognition, Participation' in N. Fraser and A. Honneth, Redistribution or Recognition?: A Political-Philosophical Exchange (Verso, 2003) 7-109.

${ }^{65}$ O'Cinneide, 'The Problematic of Social Rights', n. 33 above.

${ }^{66}$ Atrey, 'The Intersectional Case of Poverty in Discrimination Law', n. 42 above.
} 
disadvantages associated with poverty, and too fixated on grounds or status groups considered independently and in isolation of the poverty which exists within them. ${ }^{67}$

In other words, much work on intersectionality has focused on the overlapping and reinforcing impact of the standard forms of discrimination recognised in equality law (i.e. the ascribed identity grounds of race, sex, disability and so on). In contrast, the impact of poverty and material inequality has often been left out of the picture - in part because of the lack of legal recognition of this key aspect of inequality. This has arguably impoverished intersectionality discourse and blunted its critique of the traditional 'single-axis' ascribed identity approach: a major limitation of this approach, namely its lack of a 'poverty dimension' and the intersectional consequences that flow from that, has been glossed over. ${ }^{68}$

But the emergence of social rights adjudication, in both its direct and indirect forms, has opened up a new front for intersectionality critique. While still embryonic in form (a qualifier that deserves repeated emphasis), it offers a set of legal tools which can engage with the intersectional effects of poverty and material inequality - as demonstrated by the use of 'group vulnerability' as an evaluative tool for assessing the adequacy of state action in the caselaw of the ECtHR, ESCR and CESCR already discussed. Furthermore, by establishing new legal avenues for challenging unequal treatment linked to poverty, social rights jurisprudence has the potential to focus attention on how such inequality contributes to individual and group subordination, and, by extension, on its intersectional impact. In essence, it puts a legal spotlight on poverty and material inequality that has hitherto not been much in evidence - and, by extension, has the potential to add the missing 'poverty dimension' that is often glossed over in intersectionality critique.

In general, social rights discourse needs an intersectional dimension extending beyond the specific impact of poverty and material inequality, just as existing intersectionality discourse relating to ascribed identity discrimination needs a material inequality/socioeconomic rights dimension. The new emerging social rights jurisprudence - and in particular the use of 'group vulnerability' as an evaluative tool by the ECtHR, ECSR and CESCR -

\footnotetext{
67 ibid.

${ }^{68}$ See Atrey, ibid, 411: 'this way, grounds serve as the gatekeepers of discrimination law and seldom admit poverty or its attendant deprivations like homelessness, unemployment, starvation, malnutrition or illiteracy in the inner circle of protected characteristics'. See also Malleson, n. 6 above.
} 
attempts to merge these two parallel tracks. In so doing, this case-law highlights the oftneglected poverty/material inequality dimension to intersectionality, while also demonstrating the importance of intersectional analysis to the development of any serious social rights jurisprudence. ${ }^{69}$ There is a possibility here of a virtuous feedback loop opening up: the evolution of social rights adjudication may draw more attention in general to the poverty/material inequality dimension to intersectionality, while itself being enriched and deepened by the multi-faceted perspectives on inequality generated by intersectional critique.

Also, it is clear that the intersectional dimension to social rights jurisprudence is capable of being widely applied. The adequacy of state delivery of social goods, such as education, welfare and health often varies significantly in terms of its impact on groups caught at the intersection of different modes of social exclusion. ${ }^{70}$ As such, vulnerability analysis informed by intersectional perspectives has plenty of issues on which to 'bite'.

For example, in the UK, austerity cuts introduced in the early 2010s have been subject to repeated legal challenges under art. 14 ECHR on the basis that they had a disproportionate impact on a variety of different groups defined by the intersection of vulnerable socioeconomic status and standard identity grounds - such as domestic carers, certain categories of persons with disabilities, and victims of domestic violence. ${ }^{71}$ (JD and AvUK is a Strasbourg continuation of one of these domestic challenges). Some have been successful, some not. But, taken together, they illustrate the fertile ground that has been opened up even within indirect forms of social rights jurisprudence for intersectional inequalities to form the basis of legal challenges.

Intersectionality has, thus, much to contribute to the emergence of social rights jurisprudence - as social rights jurisprudence does for intersectional critique. Furthermore, the emerging intersectional dimension to social rights protection is already proving to be a highly significant component part of this case law. As channelled in particular via the evaluative concept of 'group vulnerability', intersectionality is being used to add more depth and

\footnotetext{
${ }^{69}$ Indeed, it is likely that social rights jurisprudence will draw heavily upon legal and conceptual developments in other areas of law concerned with equality: see M. Stein, 'Disability Human Rights' (2007) 95 California Law Review 75-121.

${ }^{70}$ Goldblatt, n. 43 above.

${ }^{71} R$ (Rutherford) $v$ Secretary of State for Work and Pensions [2016] UKSC 58; Hurley v Secretary of State for Work and Pensions [2015] EWHC 3382 (Admin).
} 
substance to the review of state action impacting on the enjoyment of social rights, and as an analytical tool for coming to grips with the complex ways in which social inequalities are generated and sustained. This reflects the wider ambitions of intersectionality critique more generally, and shows that it has the capacity to be applied beyond the narrow limits of antidiscrimination law. Indeed, it demonstrates that intersectionality is relevant across the full spectrum of human rights law and discourse, on account of how it helps to sharpen comprehension of how overlapping forms of disadvantage may generate rights violations - and also because of how it helps to dissolve artificial conceptual boundaries between different categories of fundamental rights, and in particular between social rights and equality/nondiscrimination entitlements. ${ }^{72}$

However, before acclaiming all this as a straightforward 'win' for the ambitions of intersectionality, a cautionary note must be added. The emerging intersectional dimension to social rights jurisprudence is also bringing to the fore some conceptual tensions that are immanent to intersectionality critique in general. These tensions complicate the attempt to develop this intersectional dimension to social rights adjudication - and also raise interesting questions about the extent to which intersectionality can be given effect through law more generally.

\section{The Risks of Intersectionality when Applied in the Context of Social Rights}

\section{Adjudication}

The progenitors of intersectionality have always emphasised that it can and should be applied across all the major overlapping forms of structural inequality in contemporary society including poverty and material inequality. ${ }^{73}$ However, as already discussed, intersectionality critique has been primarily developed and applied with reference to established nondiscrimination grounds, such as race and gender - while the overlapping impact of poverty and material inequality has often been ignored.

This situation may, as this chapter has argued, change with the emergence of social rights jurisprudence. However, it remains the case that intersectionality is widely viewed as

\footnotetext{
${ }^{72}$ I am grateful to Shreya Atrey for this point.

${ }^{73}$ See e.g. The Combahee River Collective Statement, n. 3 above.
} 
predominantly concerned with the overlapping impact of identity grounds, such as race, gender and disability. Furthermore, discrimination law, as it relates to these identity grounds, is much better developed than social rights jurisprudence, and it will often have greater credibility within domestic legal systems in particular - while the NGO/activist infrastructure that has been built around issues, such as race and sex discrimination, is often much more developed than is the case for poverty/material inequality.

As a result, there is a risk that the development of an intersectional dimension to social rights jurisprudence will generate case law and a set of associated legal outcomes and standards which focus predominantly on the impact of discrimination based on these established identity grounds - while neglecting or down-playing the exclusionary impact of poverty/material inequality, taken together with identity grounds. Litigants may be happier to focus their arguments on the former set of norms rather than develop arguments around the latter. ${ }^{74} \mathrm{~A}$ similar temptation may apply to courts and other adjudicatory bodies applying direct or indirect modes of social rights adjudication. ${ }^{75}$ This is understandable: existing legal standards relating to grounds-based discrimination are more evolved than those applying to the poverty/material inequality side of the equation, and thus are easier to rely upon. But this may result in a lopsided growth of intersectional social rights jurisprudence, with the overlapping impact of inequalities linked to income or class giving way to the impact of more familiar and legally established forms of discrimination. This, in turn, risks limiting the development of social rights jurisprudence, and contributing to the elision of poverty and material inequality as key determinants of inequality.

Furthermore, intersectional critique tends to place considerable emphasis on the need to take account of how overlapping patterns of social exclusion can have a particular impact on specific groups, with a view to adding more groups to the list of "who or what counts for

\footnotetext{
${ }^{74}$ This is illustrated by many of the collective complaints relating to the European Social Charter litigated before the ECSR. In many of the intersectional cases mentioned above, such as ERRC v Bulgaria, Complaint 48/2008 (Decision on the Merits 31 March 2009), the pleadings of the NGOs initiating the complaints were often much more developed in respect of the overlapping impact of identity discrimination than they were in respect of the impact of poverty/material inequality.

${ }^{75}$ For example, CESCR General Comment No. 20 on non-discrimination in economic, social and cultural rights only devotes six lines to outlining when discrimination on the basis of socio-economic status may breach the requirements of the Covenant, with a few more lines devoted to acknowledging the possibility of multiple and intersectional discrimination - while the rest of the Comment focuses on standard identity grounds, such as race and sex discrimination. See UN Committee on Economic, Social and Cultural Rights (CESCR), General Comment No. 20: Non-discrimination in economic, social and cultural rights (art. 2, para. 2, of the International Covenant on Economic, Social and Cultural Rights), 2 July 2009, E/C.12/GC/20 [35].
} 
purposes of equality protection in law' ${ }^{76}$ In other words, it aims to expand legal cognisance of intersectional forms of discrimination, and how they impact upon specific social groups. However, when applied in the context of social rights adjudication, this focus on highlighting intersectional group disadvantage risks obscuring the prior question of what constitutes the minimum baseline floor of treatment which all individuals and groups must enjoy as of right. In other words, a concern with securing equality of treatment across a spectrum of different social groups, reflecting the origins of intersectionality as a critique of the specific limits of anti-discrimination law, might divert attention away from the core ambition of social rights adjudication - namely to set out the dignitarian substance of such rights that should be universally enjoyed by all members of a given society. ${ }^{77}$

These concerns can be exaggerated. Indeed, the evaluative 'group vulnerability' approach discussed above, as applied by the ECSR in particular, is primarily concerned with identifying what constitutes the minimum level of support that a state should provide to a specific social group: it integrates dignitarian and equal treatment concerns into a contextual analysis of what respect for social rights entails in relation to the specific needs of a specific group of individuals defined by reference to shared vulnerabilities. ${ }^{78}$ However, as Conaghan has argued, the legal imagination as it relates to intersectionality is often narrowed by its tendency to refer back to its original starting point, i.e. a focus on the intersecting impact of ascribed identity grounds such as race and sex. ${ }^{79}$ As a consequence, there is a risk that a hypertropic growth of intersectionality within social rights jurisprudence may stunt the development of its universalist dimension, by encouraging a focus on group disadvantage when wider issues of general baseline provision are at stake. ${ }^{80}$

Arguably, these concerns need to be factored into the application of intersectional approaches in the context of social rights jurisprudence. The ECSR confronted them directly

\footnotetext{
76 J. Conaghan, 'Intersectionality and the Feminist Project in Law', n. 58 above; also, by the same author, 'Intersectionality and UK Equality Initiatives' (2007) 23(2) South African Journal of Human Rights 317-334.

${ }^{77}$ Similar concerns have been expressed at the political level, about the potential for intersectionality critique to divert focus away from arguments in support of universal social provision or to disaggregate general issues of social justice into a disparate set of identity group-focused claims. See e.g. A. Haider, Mistaken Identity: Race and Class in the Age of Trump (Verso, 2018).

${ }^{78}$ See e.g. the decision of the ECSR in Complaint 46/2007, ERRC v. Bulgaria, referred to at n. 47 above.

${ }^{79}$ Conaghan, 'Intersectionality and the Feminist Project in Law', n. 58 above.

${ }^{80}$ This risk is amplified by how indirect forms of social rights adjudication will often involve the application of non-discrimination analysis, as happens under ECHR cases where Article 14 of the Convention is invoked to challenge cuts in welfare benefit, rather than direct engagement with substantive social rights guarantees.
} 
in its decision on Collective Complaint No 48, European Roma Rights Centre v Bulgaria. ${ }^{81}$ This case concerned the adoption by Bulgaria of US-style 'welfare roll' reforms, whereby individuals receiving unemployment insurance for an extended period of time would lose entitlement to that benefit. The complainant NGO argued that this measure would have a disproportionate impact on Bulgaria's vulnerable Roma minority, who suffered from high degrees of unemployment, and therefore argued that the reforms constituted indirect discrimination on the grounds of race. However, the majority of the Committee concluded that the reforms would impact, with equal seriousness, all individuals deprived of unemployment benefit - and that a total deprivation of welfare support in this way would breach the universal guarantee of access to social assistance set out in art. $13 \S 1$ of the Social Charter. The majority thus treated the specific disadvantage faced by Roma in receipt of unemployment assistance (an intersectional category) as subsumed within the wider breach of the right to social assistance (a universal category), conscious of how the disadvantage in question would impact equally on everyone denied access to welfare. In so doing, they framed their conclusion in terms of a breach of universal minimum standards, rather than as an intersectional violation or 'single-axis' discrimination - which arguably better reflected the 'essence' of the rights violation at issue. ${ }^{82}$

Another potential concern is that intersectionality analysis places heavy reliance on the 'relative disadvantage' paradigm adopted by equality and non-discrimination law taken as a whole-i.e. it generally defines wrongful behaviour by reference to groups suffering less favourable treatment based on a combination of grounds, as compared to the treatment of other such groups. However, establishing whether such 'relative disadvantage' exists can be a challenging exercise - which is amplified in the context of social rights adjudication, given how state measures affecting entitlement to education, health care, welfare and other forms of social rights may impact on different groups in a variety of different ways.

In the academic literature on intersectionality, it is generally recognised that the traditional rigid comparator approach applied in 'single-axis' discrimination case law is very difficult (if not impossible) to apply to intersectional discrimination. Instead, a more 'contextual' approach is required - which zeroes on the concrete disadvantages generated by

\footnotetext{
${ }^{81}$ Decision on the Merits 31 March 2009.

${ }^{82}$ The author was a member of this majority. Three members of the Committee dissented on this point, taking the view that a separate violation of the Charter was made out on the grounds of indirect race discrimination.
} 
intersectional discrimination in respect of a particular group within a particular field of activity, while abandoning the usual requirement to point to a comparator in a directly analogous situation. ${ }^{83}$

As already noted, this approach chimes with the 'substantive turn' in equality and human rights law, and it is reflected in the development of group vulnerability analysis. It has particular appeal in the social rights field, given the wide variety of circumstances in which vulnerable groups can be caught up in the overlap of poverty-based exclusion and other forms of structural discrimination - and how such groups may be affected in very distinct ways by the complex and often byzantine structure of state systems of social welfare provision.

However, there is inevitably going to be some scepticism about the appropriateness of adopting such a 'contextual' approach. The very thing about this approach that attracts proponents of intersectionality - its focus on the specific situation of a vulnerable group - may repel supporters of a more formal, cautious understanding of equality. From this latter perspective, the singling out of a particular group for special protection may beg the question as to why this group should be treated any differently to other groups who find themselves in a similar state of disadvantage. Questions may also arise about how homogenous the group are, and whether an 'over-broad concept of vulnerability and dependence' is being applied in a given situation. ${ }^{84}$

Furthermore, sceptics can argue that the complexity of such systems of social provision, and the multiplicity of different groups that are affected in different ways by the intersectional impact of poverty/material inequality and other grounds, are actually arguments that tell in favour of judicial non-intervention. In general, social rights are viewed as an area where courts and other adjudicatory bodies should tread with great caution: they are often viewed as lacking the expertise and democratic legitimacy to assess the legitimacy of the various trade-offs that states make in giving effect to such rights. As such, the multifaceted nature of intersectional disadvantage when poverty/material inequality is taken into account, and the sheer number of

\footnotetext{
${ }^{83}$ S. Atrey, 'Comparison in Intersectional Discrimination' (2018) 38(3) Legal Studies 379; I. Solanke, 'Putting Race and Gender Together: A New Approach to Intersectionality' (2009) 72(5) Modern Law Review 723.

${ }^{84}$ See the partially dissenting opinion of Judge Sajó in M.S.S. v Belgium and Greece (2011) EHRR 108, who raised these points of concern about the majority's assumption that asylum seekers were a particularly vulnerable group (as opposed to other persons dependent upon state welfare support) for the purpose of assessing whether the basic level of welfare support given to them by the Greek government satisfied the requirements of art. 3 ECHR. See also Peroni and Timmer, n. 18 above, at 1083.
} 
different groups that could be classed as 'vulnerable' in contemporary socio-economic conditions, could be cited as an additional reason for human rights law to be reined in and not extended in this context. ${ }^{85}$

These sceptical arguments can be answered. The impact of intersectional discrimination is real, with the overlapping impact of poverty and material inequality often amplifying its consequences in unfair ways. Furthermore, the 'group vulnerability' approach offers a way of identifying particularly exposed groups without disappearing down a comparative 'rabbit-hole' involving endless and indeterminate group comparison. It takes account of historical context and contemporary socio-economic reality in evaluating the adequacy of state action as it impacts upon social groups at particular risk of destitution or socio-economic marginalisation, and focuses on identifying the minimum baseline of provision that such groups should receive rather than assessing the comparative favourableness of their treatment as opposed to others. ${ }^{86}$

Having said that, the potential objections of sceptics signal the need for the group vulnerability approach to be applied with rigour. ${ }^{87}$ Assumptions of group vulnerability should be backed up by compelling argumentation, and objective justification analysis applied with due regard for the complexity of decision-making relating to social rights. ${ }^{88}$

Taken together, these concerns suggest that an intersectional approach to social rights adjudication needs to be applied with one eye on its potential downsides. This does not mean abandoning the ambitions of intersectionality. However, its limits need to be recognised - along

\footnotetext{
${ }^{85}$ For an example of this line of argument, see the dissenting opinions of Judges Pejchal and Wojtyczek in the ECHR case of $J D$ and $A v U K$ (already discussed above). They concluded that there were insufficient grounds for treating female victims of domestic violence as a uniquely vulnerable group when compared to other groups also affected by the housing benefit cuts at issue in that case - and emphasised that courts should be slow to second guess how governments handle the difficult classification decisions that inevitably have to be made in allocating welfare resources.

${ }^{86}$ For more on this point, see Peroni and Timmer, n. 18 above.

87 ibid, 1083-5.

${ }^{88}$ Thus, in $J D$ and $A \cup U K$, in concluding that the UK had discriminated against female victims of domestic violence by not exempting them from benefit cuts designed to encourage families living in oversized public housing to downsize to smaller accommodation, the majority of the Court highlighted how the UK government had recognised the symbolic and emotional importance of ensuring that victims of domestic violence were to remain in their homes - a goal which the benefit cuts undermined. In so doing, the Court distinguished the treatment of this group with the treatment afforded to another group of claimants, namely disabled persons living in accommodation, which had been adjusted to meet their needs: discretionary funds were available to limit any negative impact on this second group, and there was no similar policy imperative to maintain a continuous residence in one place.
} 
with the importance of universal minimum standard-setting to this new and embryonic area of law.

\section{Conclusion}

The ambition of intersectionality to reconfigure 'single-axis' concept of discrimination is gradually being extended to encompass the overlapping impact of poverty and material inequality. This ambition is reflected in the development of social rights adjudication, where intersectional concerns - often refracted through 'group vulnerability' analysis - loom increasingly large in the existing case law. This is a healthy development, reflecting the need for an intersectional approach in this context which engages with the interlocking impact of poverty, material inequality and other forms of identity ground discrimination. There are risks involved in developing such an intersectional approach, and plenty of potential wrong turns. However, these can be contained, especially if the 'group vulnerability' approach is applied with due caution and rigour - and due attention paid to what should be the core ambition of social rights adjudication, namely to set out minimum baseline standards capable of being applied across the whole of society. 